\title{
A NEW SPECIES AND TWO NEW SUB-SPECIES OF THE GENUS ANOLIS
}

\author{
Chapman Grant, Major U. S. Army
}

Anolis roosevelti sp. nov.

Trpe: No. 1884, male, Chapman Grant Collection, Culebra Island, Porto Rico, 22 April, 1931; collector, Chapman Grant.

Diagnosis: A giant Anolis of the A. cuvieri type. Top of head deeply grooved. Ear opening triangular. Lower loreal row small. Head more pointed than in $A$. cuvieri viewed both from side and above.

Habitat: Culebra island.

Proportions: Similar to A. cuvieri except head which is more slender and pointed. Larger than any specimen of $A$. cuvieri of which I can find any record.
DESCRIPTION :
A. cuvieri
A. roosevelti

Top of head
occipital
lower loreal row
ear opening
dorsal ridge
scales on chin
rows between rays
loreal surface
Measurements of
Sschmidt's "largest
specimen", 1928.
length of head
breadth of head
arm
leg
body

flat deeply grooved. barely noticeable fairly prominent largest small small, oval large, triangular 50 spines 70 small spines keeled not keeled 3 to 4 5 vertical sloping

A further difference is that if the loreal ridge were projected to intersect the line of the cutting edge of the upper jaw they would intersect in $A$. cuvieri beyond the end of snout and in A. roosevelti at end of snout.

The supraocular semicircles leave a deep groove from the occiput 
of the males are uncommon on Porto Rico, but predominate on the keys just east of Porto Rico and on Mona Island.

Anolis cristatellus wileyi subsp. nov.

HaвiтAт: Culebra Island and adjoining keys.

Trpe: No. 1885, Chapman Grant Collection, Culebra Is., P. R. collector, Chapman Grant. 15 April 1931.

Diagnosis: Similar to Anolis cristatellus cristatellus except that the throat fan of the male has an edging of not less than one-half the radius of very deep orange. The females have the entire patch deep orange. This is constant.

During a ten day collecting trip I preserved 41 specimens, handled many more and observed hundreds of Anolis cristatellus wileyi. There was no exception to the wide, deep orange edge of the fan. The difference between this and the Porto Rican species is striking. High tail fins are more numerous than on Porto Rico. A preserved specimen resembles Anolis cristatellus cristatellus.

Named in honor of Grace Olive Wiley.

Anolis cristatellus cooki subsp: nov.

Habitat: Brea Point, S. W. Porto Rico.

Type: No. 780. Chapman Grant Collection, Brea Point, P. R., eollector, Chapman Grant. 28 Dec., 1930.

Diagnosis: Similar to Anolis cristatellus cristatellus except that the entire throat fan is chocolate color, and a light line beginning on the upper labials extends above the front leg, thence diagonally down to the groin.

The southern side of Punta Brea, SW of Guanica is desert-like. A few shrubs and cactus grow among coral slabs. In an area 100 by 500 yards in extent I found a few small, slender cristatellus with uniform chocolate colored fans. The body color was nearly white. I attach no significance to the white color or the small size, since I took only five specimens. There were no intermediate forms and no specimens inhabited the area between this little colony and the north side of the point where the bull headed, orange and green fan Anolis cristatellus cristatellus was found. In alcoh'ol these specimens remain lighter than the Porto Rico form, but the peculiarity of the fan is lost to a great extent.

Named in honor of Dr. Melville T. Cook.

This little colony forms a link between Anolis cristatellus cristatellus, D. \& B. and Anolis monensis Stejneger. It resembles the 
to near the snout. At center of ridges, groove is half as deep as wide. The canthus rostralis and semicircle have a groove between them half way to snout. Two median ridges from line with fore part of orbits to near snout inclose a deep groove and form two lesser grooves with the projection of supraocular semicircles. Thus at level with fore part of orbits there are five distinct grooves.

Fin on tail very high. Third from distil ray twice as long as depth of tail. The fourth proximal ray as long as depth of tail.

Scales on side of tail larger than in $A$. cuvieri which in turn are larger than in $A$. ricordii.

At 5th ray from

$\begin{array}{cccc}\text { base of tail : } & \text { A. cuvieri } & \text { A. ricordi } & \text { A. roosevelti } \\ \text { longitudinal rows } & 10-14 & 16-20 & 10 \\ \text { vertical rows } & 3-4 & 5-6 & 5\end{array}$

A comparison with Stejneger's 1904 Figs. 85-86 shows that $A$. roosevelti differs from $A$. ricordii greatly in the grooves on the head.

CoLor: Living specimen; brownish gray with two light lines on each side. One from ear to groin, the other from shoulder to groin. A distinct light spot on temple. Eyelids yellow. Fan gray except lower rear quarter which is light yellow. Tail yellowish brown. Underside whitish.

Named in honor of Theodore Roosevelt Jr., Governor of Porto Rico.

One specimen taken.

TWO NEW SUB-SPECIES OF ANOLIS CRISTATELLUS

Anolis cristatellus cristatellus Dumeril and Bibron, on Porto Rico runs the gamut of all the color changes and patterns known or imagined. After eight months of intimate contact with them, during which time I have preserved well over 300, picked up and handled many more and watched literally thousands, I still occasionally see a pattern or color combination new to me. The females are the ones that show the most marked diversity. One thing, however, I consider of sub-specific value. That is the colors of the throat fan. Unfortunately these do not last well in alcohol. The colors fade and the fan becomes stiff and shriveled. On Porto Rico the fan varies from a uniform light olive green throughout to a light green center edged with orange. The orange edge seldom equalling one half the radius of the fan and usually only a narrow edging. In some cases the light orange extends up on the sides of the neck. High tail fins 
latter in having the oblique lateral light line and in having the fan a uniform color, but lacks the specific transocular dusky line. I have noted in handling many fresh or living Anolis monensis that the fan is almost invariably of one color-orange yellow. Occasionally one is seen with a suggestion of green in the center of the fan and occasionally an orange fan is seen, but never the deep orange of the Porto Rico form (A. c. c.) At Playa Sardinera on Mona Island I have seen specimens with a lavendar metallic luster on the head and on the tail fin. The belly of Anolis monensis averages much brighter deeper yellow than the other forms. Stejneger, 1904, p. 646 in describing Anolis monensis says: ". . a distinct transocular, dusky line. In many specimens there is a distinct white line from shoulder to groin. The color of the dewlap can not be made out in alcoholic specimens, but there are indications that it is different from that of Anolis cristatellus." This description was based on 14 specimens. It is fully supported by the 185 specimens in my collection. Barbour, 1930 admits the validity of Anolis monensis. Schmidt, 1928 considered it synonymous with Anolis cristatellus cristatellus.

\section{Explanation of Plates XXVI-XXVII}

Fig. 1. Anolis roosevelti sp. nov. Note pointed snout and high occipital region.

Fig. 2. Anolis cuvieri Merrem. Note blunt snout and low head. Figs. 1 and 2. Life size.

Fig. 3. Anolis roosevelti sp. nov. Note deep grooves on head; prominent occipital; pointed snout.

Fig. 4. Anolis cuvieri Merrem. Note flat head; absence of visible occipital scale.

Figs. 3 and $4.11 / 4 \times$ natural size. 


\section{PLATE XXVI.}

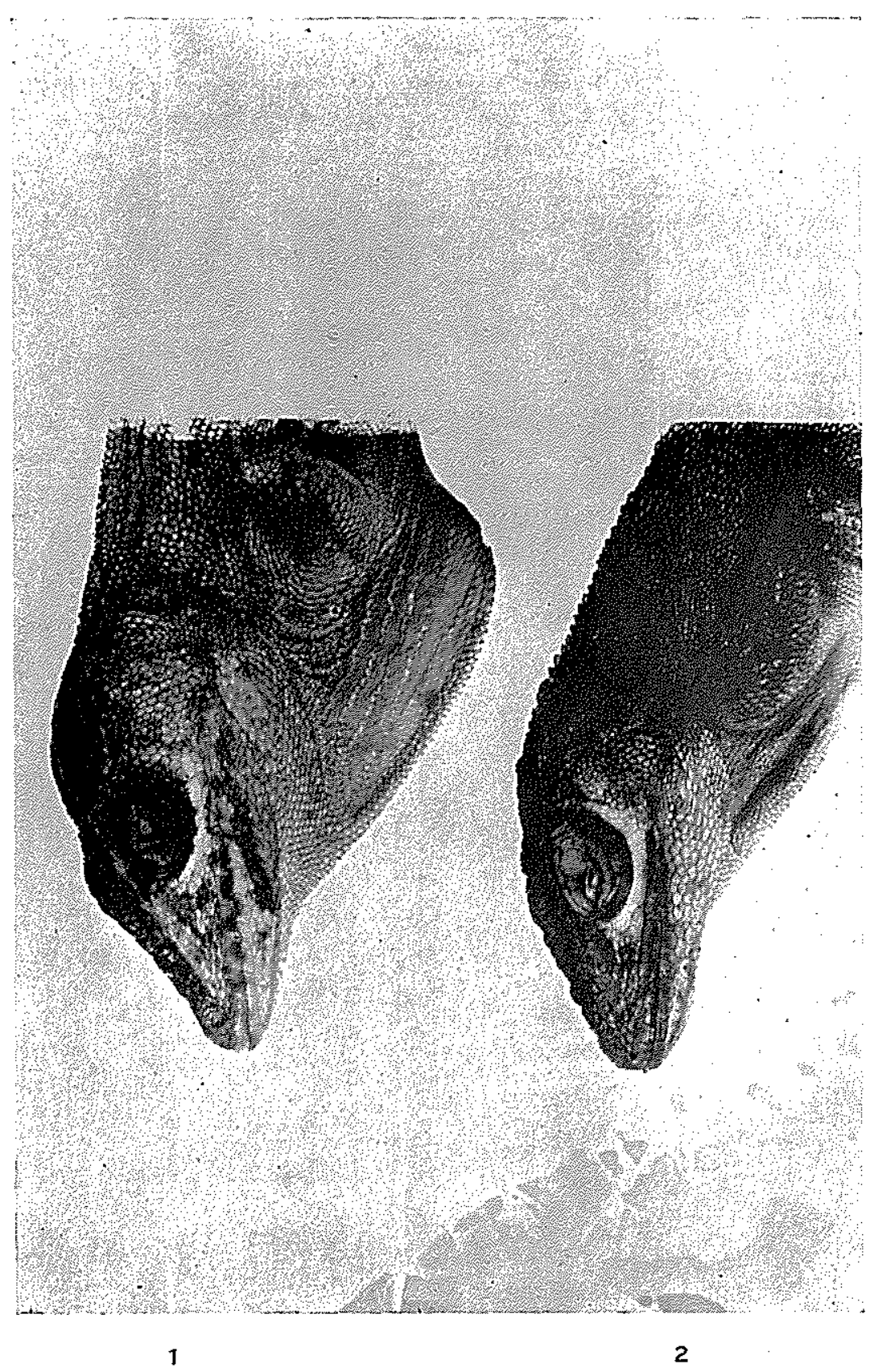




\section{PLATE XXVII.}

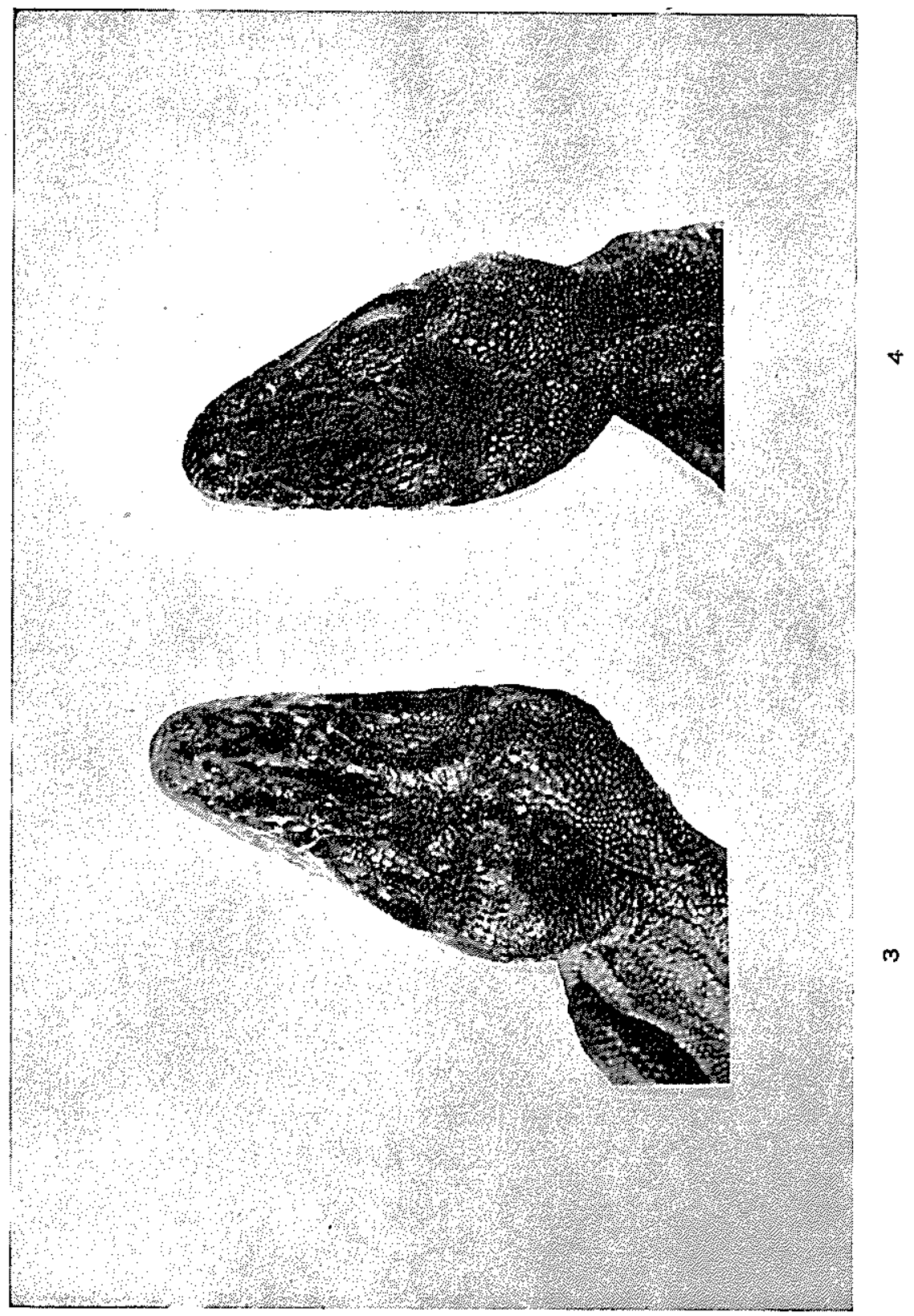

